\title{
UU ITE TENTANG EFEK MEDIA SOSIAL TERHADAP GENERASI MILENIAL
}

\section{ITE ACT ON THE EFFECT OF SOCIAL MEDIA ON THE GENERATION OF MILENIAL}

\author{
Andre Pebrian Perdana, S.I.P.,M.I.P ${ }^{1}$, Winardi Yusuf ${ }^{2}$ \\ Fakultas Hukum Universitas Malahayati \\ 1 andrepebrian@malahayati.ac.id, ${ }^{2}$ winardiyusuf0405@gmail.com
}

Dikirim 2 Desember 2020, Direvisi 12 September 2020, Disetujui 24 November 2020

\begin{abstract}
Abstrak : Media sosial merupakan suatu alat telekomunikasi yang saat ini berkembang sangat cepat, perkembangan media sosial tentunya membawa pengaruh yang sangat signifikan terutama dalam aktivitas sehari-hari, media sosial yang saat ini dianggap sebagai kebutuhan primer menyebabkan banyak sekali konten-konten yang menjadikan media sosial sebagai referensi masyarakat untuk mencari atau memberi informasi terkait. hal-hal yang sedang terjadi ataupun konten-konten yang sedang tren saat ini.Namun dalam realisasi di media sosial banyak pengguna yang kurang mengetahui dan memahami landasan hukum yang ditetapkan oleh pemerintah, sehingga pengguna tanpa menyadari kosekuensi terkait berlebihan dalam penggunaan media sosial, seperti memposting hal-hal negatif dan informasi yang mengandung SARA.

Tujuan penelitian ini untuk mengetahui UU ITE tentang Efek Media Sosial Terhadap Generasai Melenial. Metode yang digunakan adalah metode deskriftif teknik pengumpulan data data adalah teknik wawancara dan kuisoner, sedangkan teknik analisis data kualitatif.

Hasil dari penelitian ini bahwa UU ITE Tentang Efek Media Sosial Terhadap Generasi Melenial yaitu, UU ITE sebagai barometer aktivitas generasi melenial terhadap pengaruh media sosial, UU ITE membatasi aktivitas generasi melenial dalam berekspresi di media sosial, UU ITE benteng untuk memfilter pengaruh buruk yang masuk melalui media sosial terhadap perkembangan generasi melenial dan wujud perkembangan teknologi yang menyebar secara menyeluruh kesegala penjuru dunia.
\end{abstract}

Kata Kunci: UU ITE, Media Sosial, Generasi Melenial

Abstract : Social media is a telecommunication tool that is currently developing very fast, the development of social media certainly has a very significant influence, especially in daily activities, social media which is currently considered a primary need causes a lot of content that makes social media a community reference to find or provide information related to things that are happening or content that is currently trending. However, in the realization on social media, many users do not know and understand the legal basis set by the government, so that users are unaware of the consequences related to excessive use of social media, such as posting negative things and information containing SARA.The purpose of this study was to determine the ITE Law on the Effects of Social Media on Melenial Generations. The method used is descriptive method. Data collection techniques are interview and questionnaire techniques, while the data analysis techniques are qualitative. The results of this study indicate that the ITE Law on the Effects of Social Media on the Melenial Generation, namely, the ITE Law as a barometer of the activity of the millennial generation on the influence of social media, the ITE Law limits the activities of the melennial generation in expression on social media, the ITE Law is a fortress to filter out bad influences that enter through social media towards the development of the melenial generation and the form of technological developments that have spread throughout the world.

Keywords: ITE Law, Social Media, Melenial Generation

\section{PENDAHULUAN}

\author{
Pasal 1 ayat (3) UUD 1945 dengan \\ tegas menyatakan bahwa Negara \\ Indonesia adalah negara Hukum. Salah
}

satu unsur penting dari suatu negara yang berlandaskan hukum adalah adanya perlindungan terhadap hak-hak asasi (Luh Gede Mega Kharisma, 2016, Kedudukan Komisi Nasional Hak Asasi Manusia Sebagai Lembaga Negara 
Independen

Dalam

Sistem

Ketatanegaraan Indonesia, Jurnal Kertha Negara, Vol. 04, No. 05, Juli 2016, URL

https://ojs.unud.ac.id/index.php/Kerthan egara/article/view/21976/14575, h.2). Kebebasan untuk mengelola dan memperoleh informasi adalah hak asasi manusia yang harus dipenuhi dan dilindungi oleh Negara. Sejak bertahuntahun lalu, dunia internasional mengakui bahwa hak kebebasan informasi adalah hak asasi dasar dan merupakan tanda dari seluruh kebebasan yang akan menjadi titik perhatian PBB (Sirajuddin, Didik Sukriono, Windardi, 2011, Hukum Pelayanan Publik Berbasis Partisipasi dan Keterbukaan Informasi, Setara Press, Malang, h.108). Pada Dasarnya, informasi yang bebas di setiap Negara ditujukan agar lembaga publik lebih terbuka dan kredibel dengan menunjukan informasi sesuai dengan padangan dan minat publik. Oleh sebab itu maka dapat dikatakan bahwa informasi yang terbuka dan menganut prinsip kebebasan merupakan salah satu hal yang harus dapat terpenuhi agar tercapainya pemerintahan yang baik (good governance) (Endang Retnowati, 2012, Keterbukaan Informasi Publik dan Good Governance (Antara Das Dein dan Das Solen), Jurnal Perspektif, Vol. 17, No. 1 Januari 2012, URL : http://jurnalperspektif.org/index.php /perspektif/article/view/94/86, h. 55). Dalam Pasal 28F Undang-Undang Dasar 1945 menegaskan bahwa semua orang berhak untuk menggunakan segala fungsi dan akses dari sebuah informasi baik elektronik maupun non eletektronik yang tersedia dalam berbagai bentuk seperti gambar, bunyi, video, tulisan dan lainnya melalui media media atau saluran yang sudah tersedia. Dengan demikian maka kebebasan terhadap informasi bukan hanya sebagai hak asasi, melainkan juga hak yang dijamin dan diakui keberadaannya oleh kontitusi Indonesia
(Nunuk Febriananingsih, Keterbukaan Informasi Publik Dalam Pemerintahan Terbuka Menuju Tata Pemerintahan Yang Baik, Jurnal Rechts Vinding, Vol. 1, No.1 Januari - April 2012, URL : https://rechtsvinding.bphn.go.id/ejournal /index.php/jrv/article/view/110, h.136).

Media sosial merupakan sebuah teknologi komunikasi berbasis online yang menjadi sebuah alat komunikasi antar sesama manusia, media sosial adalah media pergaulan yang dilakukan secara online dengan menggunakan internet. Pengguna media sosial dapat berkomunikasi, menjalin pertemanan, mengirim pesan antar satu pengguna ke pengguna media sosial lainnya serta mengirim foto. Kaplan dan Michael Haenlein menyatakan bahwa media sosial merupakan sebuah aplikasi yang berbasis internet dan teknologi Web 2.0 yang dapat memuat pertukaran sebuah pesan atau konten (Kaplan, Andreas M.; Michael Haenlein. 2010. Users of the Word, United The Challenges and opportunities of Sosial Media. Business Horizons 53 (1): 59-68).

Media sosial merupakan salah satu alat dan komunikasi berkembang dimasa sekarang, semua kalangan baik dari anakanak, remaja, sampai dengan orang tua dapat menggunakannya dengan sangat mudah, akses yang digunakanpun cukup mudah yaitu hanya dengan menggunakan smartphone setiap kalangan sudah dapat melakukan interaksi antar satu dengan yang lainnya melalui online. Perkembangan media sosial tentunya membahwa pengaruh yang cukup signifikan terutama dalam lingkungan masyarakat saat ini. Semua aktivitas masyarakat saat ini tidak terlepas dari media sosial. Dimulai dari aktivitas yang paling sederhana sampai aktivitas yang paling kompleks. Sehingga perkembangan media sosial sangat besar tak terkendali, pengaruhnya dari kotakota besar hingga keplosok desa. Masyarakat saat ini tidak jarang yang tak 
mengenal yang namanya media sosial. Apalagi saat ini dengan akses jaringan yang kuat dan media alat yang mudah didapat oleh masyarakat. Pengguna media sosial yang berkembang di Indonesia sangatlah besar bahkan jumlah pengguna yang aktif merupakan salah satu yang terbesar di dunia saat ini.

Hal ini sangat beralasan karana didukung dari data yang di peroleh kominfo mengatakan bahwa "Di Indonesia, pengguna internet mencapai 150 juta jiwa dengan penetrasi $56 \%$ yang tersebar diseluruh wilayah. Jumlah tersebut hanya selisih sedikit dengan jumlah pengguna internet mobile yang berjumlah 142.8 juta jiwa dengan persentase penetrasi sebesar 53\%.Hasil survey APJII 2018 pengguna internet masih memiliki persentase paling tinggi di pulau Jawa dan Sumatera (Kemenfo, 2019"

UU

ITE"https://www.kominfo.go.id/).

Indonesia yang saat ini sudah masuk kedalam arus era globalisasi dengan ditandainya masyarakat mudah mengakses informasi dari berbagai belahan dunia tentunya membawa pengaruh yang cukup besar baik bersifat positif dan negatif tentunya memberikan dampak kepada generasi-generasi berikutnya.

Millenial juga dikenal sebgai generasi Y, Gen Y adalah kelompok demografi setelah generasi $X$. Tidak ada batas waktu yang pasti untuk awal dan akhir dari kelompok ini. Generasi millenial pada umumnya adalah anakanak dari generasi Baby Boomers dan Gen-X yang tua. Millenial kadangkadang disebut sebagai "Echo Boomers" karena adanya booming (peningkatan besar), tingkat kelahiran pada tahun 1980-an dan 2000-an. Generasi millenial memiliki karakteristik berbeda-beda berdasarkan wilayah dan kondisi sosialekonomi. Namun, generasi ini umumnya ditandai oleh peningkatan penggunaan dan keakraban dengan komunikasi, media, dan teknologi digital. Disebagian besar belahan dunia, pengaruh mereka ditandai dengan peningkatan liberalisasi politik dan ekonomi, meskipun pengaruhnya masih diperdebatkan (Https://id.m.

Wikipedia.org/wiki/Milenial\#cite_note1).Media sosial yang saat ini dianggap menjadi salah satu kebutuhan primer dikalangan masyarakat, untuk mencari informasi, hiburan, pengetahuan pendidikan tentunya memiliki manfaat dan resiko yang cukup tinggi, jika landasan dasar peraturan-peraturan pemerintah tidak dipahami. Kemudahankemudahan yang di terima oleh kalangan masyarakat dan khususnya generasi milenial. Dengan adanya kemudahankemudahan tersebut tentunya menimbulkan suatu problema tentunya dari pengguanaan media sosial itu sendiri, banyak dari pengguna media sosial khususnya generasi millenial tidak memahami aturan-aturan dari penggunaan dan efek-efek yang akan timbul dari media sosial itu sendiri. Media sosial yang dianggap sebagai tempat untuk menyalurkan kontenkonten ataupun informasi tak jarang mengandung hal-hal negatif yang dapat menimbulkan persepsi yang berbedabeda, tentunya dengan timbulnya persepsi yang berbeda akan dapat menimbulkan perselihan antar pengguna itu sendiri terutama generasi millenial. Seperti ujar kebencian berita bohong, bullying, SARA, kriminalitas dan lainlainnya. Untuk itu dengan hadirnya masal tersebut tentunya pemerintah Indonesia telah mengeluarkan peraturan tentang media sosial agar dapat mengendalikan dan mengkontrol media sosial yang berkembang khususnya di generasi millenial. Pemerintah pusatnya atau kementrian komunikasi dan informatika memberikan membuat sebuah peraturan untuk mengontrol kendali media sosial yang berkembang di generasi melanial Indonesia. Tertuang pada "Undang- 
Undang Nomor 19 tahun 2016 tentang Perubahan Atas Undang-Undang Nomor 11 tahun 2008 tentang Informasi dan Transaksi Elektronik (Ibid, 2019 h. 1). Oleh karena itu, peneliti tertarik untuk meneliti tentang "UU ITE Tentang Efek Media Sosial Terhadap Generasi Melenial"

\section{RUMUSAN MASALAH}

Adapun rumusan masalah dalam penelitian ini yaitu bagaimana UU ITE Tentang Efek Media Sosial Terhadap Generasi Melenial yang berlaku di Indonesia.

\section{TUJUAN PENELITIAN}

Adapun tujuan dari penelitian ini adalah untuk mengetahui UU ITE Tentang Efek Media Sosial Terhadap Generasi Melenial yang berlaku di Indonesia

\section{METODE PENELITIAN}

Menurut Mardalis, metodelogi adalah suatucara atau tehnik dalam proses penelitian itu sendiri diartikan sebagi upaya dalam bidang ilmu pengetahuan yang dijadikan untuk memperoleh fakta-fakta dan prinsipprinsip dengan sabar dan hati-hati, dan sistematis untuk mewujudkan kebenaran (Mardalis. 2004. Metode Penelitian (Suatu Pendekatan Proposal). Jakarta:Bumi, hml. 24). Menurut Sugiyonostudi kepustakaan berkaitan dengan kajian teoritis dan referensi lain yang berkaitan dengan nilai, budaya dan Norma yang berkembang pada situasi sosial yang diteliti (Sugiyono. 2012. Metode PenelitianKuantitatif Kualitatif dan R\&D. Bandung: Alfabeta. Hml. 291).
Metode penelitian ini menggunakan metode deskriftif. Metode Deskriftif ini diartikan sebagai prodesur pemecahan masalah yang diselidiki dengan menggambarkan/ melukiskan keadaan / objek penelitian (seseorang, lembaga, masyarakat, dan lain-lain) pada saat sekarang berdasrkan fakta yang tampak atau sebagaimana adanya (Nawawi, Handari. 1993. Metode Penelitian Bidang Sosial. Yogyakarta: UGM Pers. Hml. 63). Variable dalam penelitaian ini adalah variable tunggal yakni UU ITE Tentang Efek Media Sosial Terhadap Generasi Melenial. Teknik pengumpulan datayang digunakan dalam penelitian ini dilakukan dengan cara.

Analisis data adalah sebuah proses untuk memeriksa, membersihkan, mengubah, dan membuat pemodelan data dengan maksud untuk menemukan informasi yang bermanfaat sehingga dapat memberikan petunjuk bagi peniliti untuk mengambil keputusan terhadap pertanyaan-pertanyaan penelitian.

\section{HASIL PENELITIAN DAN PEMBAHASAN}

\section{Perkembangan UU ITE}

Pada tanggal 25 telah terbit undang undang ITE yang mana ini telah membuktikan bahwa Indonesia tidak lagi ketinggalan dari negara negara yang lainnya dalam membuat peranti hukum di dalam bidang kejahatan internet,yang mana lebih tidak asing lagi apa bila kita sebut sebagai cyberspacelow. Dalam hal ini peran undang undang di maksudkan untuk menjawab permasalahan yang sering terjadi,yang mana ketika kita sebagai pengguna media sosial sering sekali di hadapkan dengan penyampaian informasi, komunikasi dan transaksi, secara elektronik yang mana isi di dalamnya banyak sekali pumbuktian perbuatan melawan hukum. 
Dalam hal ini pemerintah memberikan jaminan keamanan dalam penggunaan ITE, melindungi konsumen atau penggunaan internet baik dalam data atau pun Informasi tentang penggunanya. Perlindungan yang diberikan pemerintah dalam UU ITE ini berlaku kepada semua pengguna. Sebagai contoh dilaksanakan melalui sistem elektronik. Esensi UU ITE melingkupi seluruh transaksi berbasiselektonik seperti Komputer serta jaringan dan memiliki kukuatan hukum. UU ITE yang di harapkan mampu untuk mengatur seluruh sistem yang terlibat kendala hukum dengan hukum berkaitan dengan dunia internet (cyber) UU ini diperuntukan kepada pengguna yang ada di Indonesia maupun yang ada di luar. Akan tetapi lebih dikhususkanUU ITE berlaku untuk setiap orang di Indonesia yang memiliki akibat hukum Indonesia, atau seluruh masyarakat Indonesia yang di luar Indonesia yang bersangkutan dengan hukum Indonesia yang diharapkan bisa mengatur segala yang telah dia atur Undang-Undang Nomor 11 Tahun 2008 tentang Informasi dan Transaksi Elektronik ("UU ITE") sebagaimana yang telah diubah oleh Undang-Undang Nomor 19 Tahun 2016 (Wahono,RomiSatria.2008."Analisa UUITE,'http://romisatriawahono.net/200 8/04/24/analisa-uu-ite/.).

Pasal 27 ayat 3 UU ITE menyebut melarang setiap orang dengan sengaja dan tanpa hak mendistribusikan dan/atau mentransmisikan dan/atau membuat dapat diaksesnya Informasi Elektronik dan/atau Dokumen Elektronik yang memiliki muatan penghinaan dan/atau pencemaran nama baik.Undang-Undang Informasi dan Transaksi Elektronik (UU ITE) terdiri dari $13 \mathrm{Bab}$ dan 54 pasal, terdiri dari beberapa bagian yang dirangkum sebagaiberikut:

a. Penyelenggaraan sertifikasi elektronik dan sistem elektronik adalahUU ITE berlaku untuk setiap orang di Indonesia yang memiliki akibat hukum Indonesia,atau seluruh masyarakat
Indonesia yang di luar Indonesia yang bersangkutan dengan hukum Indonesia. Pelanggaran atau penyalahgunaan ITE yang berada di wilayah Indonesia, maka segala perbuatan yang tidak sesui dengan aturan ITE di Indonesia baik dari dalam maupun Luar Indonesia tetap diberlakukan.

b. Transaksi elektronik adalahPenyelenggaraan Transaksi Elektronik dapat dilakukan dalam lingkup publik ataupun privat dan para pihak memiliki kewenangan untuk memilih hukum yang berlaku bagi Transaksi Elektronik internasional yang dibuatnya serta Pengirim dan penerima transaksi elektronik yang melakukan transaksi elektronik sendiri, dengan prantara orang ke 2 yang diberikan kuasa, juga dengan agen Elektronik yang lainnya. Keduannya tetap akan diberlakukan hukuman yang sama sesui dengan UU ITE.

\section{Media Sosial}

Media social pada tahun 2014 lalu perannya banyak di gunakan sebagai senjata oleh bidang politik bahkan menjadi"senjata baru"sebagai kebutuhan kampanye. Peran media sosial sebagai alat promosi dari konsumen seperti perusahaan. Perusahaan-perusahaan saat ini memberikan perhatian khusus untuk mengelola media sosial dan menjalin hubungan yang baik dengan pelanggan mereka secara daring (dalam jaringan).Ini semua merupakan sebuah tantangan dan keadaan yang tidak bisa di pungkiri,banyaknya jumlah pengguna media sosial dapat membuktikan fakta baru yang sangat menarik betapa pentingnya pertumbuhan internet untuk kehidupan (Nasrullah, R. (2015). Media sosial (perspektif komunikasi, budaya, dan sosioteknologi). Jakarta: Simbiosa Rekatama Media, h. 77). 


\section{Defenisi Media Sosial}

Istilah media sosial bersal dari 2 kata yaitu media dan social. Media di artikan sebagai alat komunikasi sedangkan kata:social adalah di artikan sebagai fakta sosial nah wasannaya setiap individu melakukan kreativitas yang memberikan kontribusi kepada masayarakat (Laughey, D. (2007). Themes in mediatheory. New York: Open University Press, h. ). Menurut Andreas Kaplan dan Michael Haenlein mendefinisikan media sosial sebagai sebuah kelompok aplikasi berbasis internet yang dibangun diatas dasar ideologi dan teknologi Web 2.0, dan memungkinkan penciptaan dan pertukaran user-generated content. Menurut Kaplan dan Haenlein ada enam jenis media sosial: proyek kolaborasi (misalnya, wikipedia), blog dan microblogs (misalnya, twitter), komunitas konten (misalnya youtube), situs jaringan sosial (misalnya facebook, instagram), virtual game (misalnya world of warcraft), dan virtual social (misalnya, second life) (Kaplan, Andreas M.; Michael Haenlein (2010) "Users of the world, unite! The challenges and opportunities of Social Media”. Business Horizons 53(1): 59-68).

Maraknya media sosial yang menarik perhatian penulis adalah banyaknya para pengguna media sosial yang dengan sengaja memanifulasi foto profil yang tidak sesuai dengan pemilik akun resminya atau dengan sengaja membuat akun fake,terlebih lagi tidak memasang foto profil bukan foto aslinya sehingga terlihat jelas ini semua penipuan publik,terlebih lagi ada yang menggunakan media sosial tanpa identitas jelas, ironi pelaku pengguna media sosial juga memperjelas upaya-upaya mereka untuk merekontruksi identitas alamat melalui tulisan-tulisan tautan atau laman tertentu yang sesungguhnya hanya untuk memperjelas penggunanya. Untuk itu perlu ada aturan yang dibuat agar pengguna internet dapat mematuhi pedoman penggunaan yang ada. Aturan ini ada karena perangkat teknologi itu merupakan sebuah mesin yang terhubung secara daring atau bisa muncul karena interaksi diantara sesama pengguna. Fakta itu selaras dengan ungkapan dimana ia menggunakan istilah simulacra yang berarti sebagai;bukan cerminan dari realitas; kepekaan tentang suatu yang nyata terhadap pengguna media sosial semakin mengalami penurunan dan akan tergantikan oleh realitas yang semu (Baudrillard, J. (1994). Simulacra and simulation. Ann Arbor: University of Michigan Press: h. 76), kondisi ini disebabkan oleh terus menerusnya imaji yang ditampilkan oleh media secara terus menerus hingga pada ahirnya banyak masyarakat merasa berada diantara yang realitas dan ilusi karna tanda-tanda yang di media online seakan-akan tidak lagi berkaitan dengan kehidupan nyatanya dengan kata lain media sosial telah menjadi realitas itu sendiri nyata secara faktual (Nasrullah, R. (2015). Media sosial (perspektif komunikasi, budaya, dan sosioteknologi). Jakarta: Simbiosa Rekatama Media: h. 52).

\section{Generasi Millenial}

Dikenal dengan sebutan generasi millenial atau milenium. Ungkapan generasi Y mulai dipakai pada editorial Koran besar AmerikaSerikat pada Agustus 1993. Generasi ini banyak menggunakan teknologi komunikasi instan seperti email, SMS, instan messaging dan media sosialseperti facebook dan twitter. Mereka juga suka main gameonline. Generasi millenial merupakan generasi yang cepat beradaptasi dengan era digital dimana generasi millenial dapat secara cepat menggunakan media sosial bahkan generasi tersebut dapat menghasilkan uang dari media yang mereka ciptakan. Generasi millenial juga dikenal memiliki sikap mandiri karena mereka dapat melakukan hal-hal yang mereka inginkan 
dengan cara belajar melalui media sosial dan mereka juga dapat cepat beradaptasi dengan hal-hal baru seputar media sosial

\section{UU ITE Tentang Efek Media Sosial Terhadap Generasi Millenial}

Perkembangan pada masa globalisasi yang terjadi masa sekarang munculnya hal-hal baru dalam kehidupan dan gaya hidup generasi melenial. Maka dalam penyikapinnya kita harus dewasa sehingga pola pikir kita terus berkembang kearah lebih maju seiring dalam perubahan teknologi dan informatika. Dilema yang dihadapiakan selalu bermunculan baik secara internal maupun eksternal. Sikap dewasa ini membawa pada perubahan yang signifikan pada perubahan disegala segi kehidupan sekarang.Kehidupan yang awalnya lebih banyak interaksi langsung beralih ke interaksi tidak langsung. Perubahan ini memisahkan antara generasi sebelumnya dengan generasi millenial sekarang. Pola-pola yang hasilkan berbeda sehingga merubah pola fikir generasi saat ini. Pola pikir yang muncul dan berkembangkan lebih kepada gaya hidup praktis dan cepat. Pola pikir ini tidak mementingkan sebuah proses panjang melainkan bagaimana segala sesuatu yang muncul dalam pengerjaannya lebih mudah dan cepat. Perkembangan ini akan memunculkan konflik yang berkepanjangan antara generasi sebelumnya dengan yang sekarang. Konflikyang muncul pada awalnya itu tidak terasa karana dianggap sebuah perubahan gaya hidup semata, akantetapi lambat laun yang perbedaanyang muncul semakin besar. Sehingga perubahan ini membuat lubang curam yang besar dari antar generasi. Perselisih ini pun terus berlanjut sampai beberapa waktu akan datang.

Pola ini merupakan titik awal tentang penomena media sosial sebagai kebutuhan masyarakat. Terjadinya pergeseran peran dan makna dari media sosial awalnya hanya sebagai alat perubahan, lalu beralih kepada kebutuhan yang dibutuhkan oleh masyarakat. Media sosial yang dianggap sebagai gudang informasi yang dapat diterima oleh masyarakat.

Alhasil menjamurnya media sosial ini tidak luput dari perubahan-perubahan pola pikir masyarakat itu sendiri.Hal ini dengan ditunjangnya sarana prasarana yang lebih memadai dan mudah dibawa yaitu smartphone. Alat media juga semakin canggih dan mudah dibawa, sehingga semakin banyaknya pengguan yang menggunakan smartphone. Hal ini berdampak padaakses komunikasi antar individu pun sudah tidak bersekat atau terbatas lagi. Ruang pertemuan langsung pun beralih ke ruang pertemuan digital yang dianggap lebih mudah dan tidak kenal tempat. Para Pemimpinera milenial harus bisa memanfaatkan kemajuan teknologi ini untuk menghadirkan proses kerja yang efisien dan efektif di lingkungan kerjanya. Misalnya dengan mengadakan rapat via WA ataupun Anywhere Pad, mengganti undangan tertulis dengan undangan via email ataupun Telegram, dan membagi product knowledge via WA dan lainya.

\section{a. Efek Media Sosial}

Penggunakan yang terus menurus dilakukan membawa dampak yang bersifat signifikan terhadap perkembangan generasi melenial. Dampak yang dihasilkan muncul secara beragam tergantung terhadap pengguna. Efek yang muncul dari media sosial terhadap generasi melenial yaitu:

1) Karakter Atau Kepribadian

Terbangunnya karakter atau kepribadian seseorang diakibatkan suatu kebiasaan yang dilakukan secara berulang-ulang setiap hari tanpa ada paksaan atau tekanan dari pihak lain. Kepribadian yang muncul di setiap orang merupakan akibat dari faktor kebiasaan. Dalam hal ini 
pembentukan karakter didukung oleh media sosial yang sebagai kebutuhan dan pengunanya setiap hari. Perubahan yang muncul akibat media sosial butuh proses panjang sehingga membuat faktor ketergantungan dan ingin menggunakan setiap hari. Keinginan-keingan inilah yang membentuk jadi diri sesorang, sehingga dalam pembentuknya dan pola yang muncul juga berbeda. Setiap generasi memiliki ciri khas tersendiri akibat perubahan yang disebabkan hal tersebut. Perubahan tersebut membentuk sebuah keunikan tersendiri yang mana itu ciri khas generasi melenial sekarang. Karakter yang muncul juga beragam dari hal yang sifatnya lembut sampai yang frontal. Perbedaan karakter pada saat ini sesuai yang meraka lakukan pada saat ini pula. Penunjang karakter saat ini sangat mudah kita pelajari atau kita bisa meniru karakter tentu, kita bisa mengikuti atau mempelajari yang ada. Generasi melenial ini terkadang memiliki karakter ganda, akibat lingkungan yang beragam. Lingkungan berbeda membentuk diri kita baik secara sadar atau dipaksa dalammengikuti dan dapat menempatkan diri dengan lingkungan yang ada. Karakter yang terbentuk dan timbul akibat media sosial merupakan karakter yang tangguh dan dapat bersaing dengan yang lain.

Generasi melenial lebih cenderung suka bertanya dan meminta kritik serta saran untuk kemajuannya. Namun dikalangan remaja sekarang ini media sosial seakan sudah menjadi candu dimana tidak ada hari tanpa membuka media sosial. Media sosial memang menawarkan banyak kemudahan yang membuat para remaja betah berlama-lama berselancar di dunia maya, hasil riset yang dilakukan STSN (Sekolah Tinggi Sandi Negara) Indonesia menunjukan kalangan remaja usia 15-19 tahun mendominasi pengguna internet di Indonesia (64\%). Hal tersebut berpengaruh terhadap karakter remaja sehingga terbentuk karena tuntunan yang disebut sebagai suatu standard yang 'ideal' yang dimaksud adalah karakter remaja sekarang terbentuk dari apa yang dikatakan orang, dan tidak berasal dari pemikiran diri sendiri yang menyebabkan remaja tersebut akan mudah kehilangan jati dirinya sendiri.

Selain itu media sosial juga menumbulkan pro dan kontra yang mengakibatkan pengguna media sosial sering kali mengganggu proses belajar dan juga berhasil mengubah karakter remaja. Dizaman teknologi seperti sekarang ini kita dapat melihat disekitar kita mulai dari kehidupan remaja yang serba instant, memiliki ambisi besar untuk sukses, cinta kebebasan, percaya diri, dan sebagainnya.

Dan dengan adanya media sosial juga menyebabkan timbulnya kemalasan seseorang untuk melakukan sesuatu, misalnya malas mencari jawaban tugas yang dikasih dosen atau guru yang rill dari pemikiran kita sendiri melainkan memilih jawabannya dengan mencari di google. Dan semua ini merupakan pengaruh dari adanya media sosial saat ini.

\section{2) Anti Sosial}

Kehebatan media sosial yang ditawarkan kepada generasi melenial saat ini sangatlah kuat. Hal-hal yang menarik selalu disuguhkan dengan kemasan menarik. Pengguna terpengaruh dari media sosial tersebut dan terus mereka mencari hal baru dari media sosial (medsos). Ibarat medsos itu gula yang selalu membuat menarik bagi semut. Ketertarikan itu yang membuat generasi melenial bisa menghabiskan sepanjang waktu di depan media sosial. Keasikan yang didapat dari media sosial membuat mereka lebih senang dirumah dari pada pergi keluar rumah. Karena media sosial menawarkan berbagai hal seperti hiburan, kreatifitas, game, mencari pertemanan hingga berbelanja. Kebutuhan pun yang dibperlukan telah disediakan dimedia sosial sehingga tidak perlu pergi 
keluar rumah lagi. Hal ini yang menyebakan ruang interaksi atau kontak langsung dengan orang lain semakin sedikit bahkan jarang. Kebiasan ini terus berlangsung terus menurus mengakibatkan anti sosial terbangun dalam generasi melenial. Anti sosial ini kecendrungan sesorang untuk menghindari berinteraksi sosial dengan orang lain. Mereka lebih memilih hidup menyendiri dan menghabiskan waktunya dengan berselancar di dunia maya dengan media sosialnya. Semua ekspresi dan kreatifitasnya dicurahkan dalam media sosial tersebut. Apapun yang dirasakan dalam dirinya meraka curahkan dalam media sosial dalam bentuk chat atau video. Supaya teman-teman dunia mayanya dapat mengetahui yang lagi dirasakan oleh dia. Akan tetapi kalau ketemu dengan temannya yang didunia nyata cenderung tertutup. Sifat anti sosial ini menyebakan kurangnya perasaan simpati, empati terhadap kejadian kejadian disekitarnya. Mereka menganggap kejadian itu bukan bagian dari diri mereka sendiri. Permasalahan anti sosial pun semakain tinggi dan curam.

\section{3) Pengembagan Diri}

Dengan mudah mengakses tentang perkembangan di masa saat ini sehingga generasi melenial bisa menetahui perubahan yang terjadi di dunia. Hal ini berbeda saat belum merebaknya tentang media sosial di Indonesia, info-info yang didapat sangat sedikit bahkan tidak tersampaikan. Berbeda dengan masa sekarang sangat mudah bagi mereka, untuk mendapatkan informasi dan mudah mengembangkan potensi diri yang mereka miliki tanpa biaya dan dapat dilakukan dimana saja. Kita bisa ambil contoh sesorang ingin belajar menggunakan alat musik gitar, dulu kita harus minta bantuan orang lain atau ketempat kursus.Tapi sekarang sangat mudah dengan melalui media masa, mereka dapat latihan itu dengan sendiri, melalui dengan melihat video, atau aplikasi yang telah tersedia di media sosial.

Pengembangn potensi diri mudah disalurakan dan dikembangkan lebih lanjut. Generasi melenial ini cenderung lebih cepat dalam pengembangan potensi diri. Apalagi dengan niat dan semangat gigih yang mereka miliki untuk bisa bersaing dengan orang lainnya. Perlombaan-perlombaan untuk mengebangkan potensi diri semakin tinggi.Potensi yang awalnya mustahil dapat dikembang, tetapi dengan didukung dengan akses media social yang mudah potensi baru terlahir, Sedangkan potensi yang ada semakin terasah dan terlatih.

Sedemikian besarnya pengaruh media sosial dalam perkembangan potensi pada generasi melenial sanagt terpengaruh. Sampai tingkat kreativitas dan inovatif pun muncul dari generasi melenial ini. Kreatifitas yang muncul terus berkembang menjadi sebuh profesi yang dapat menghasilkan pendapatan. Pendapatan yang dipeoleh bahkan melebihi dari pendapatan orang yang bekerja di perusahan swasta atau negeri. Pengolahan yang baik dari media sosial membawa anugrah dan prestis yang baik pula bagi generasi melinial itu sendiri.

\section{b. Pembatasan Media Sosial Melalui UU ITE}

Penggunaan media sosial yang sangat besar di Indonesia. Untuk membatasi prilaku pengguna media sosial yang kurang baik atau menyimpang makanya perlu ada norma-norma atau hukum yang mengikat.Hukum yang dibuat tidaklah membatasi ekspresi dan kreativitas sipengguna melainkan untuk melindungi pengguna dari pengguna lainnya. Penggunaan media sosial mulai perlu diberi rambu-rambu yang jelas tentang penggunaan yang baik dan bermanfaat. Melalui Peraturan UU no 11 tahun 2008, pembuatan UU ini wujud kepedulian 
pemerintah terhadap pengguna media sosial. Penyimpangan-penyimpangan para pengguna media sosial mengalami pengurangan. Akan tetapi, masih banyak pengguna melakukan pelanggaran.Pelanggaran yang selalu bermunculan dari setiap priodenya, perlu UU ITE ini menerapkan lebih keras lagi dan jelas dalam koridor hukumnya, sehingga tidak ada lagi pengguna yang melanggar dapt berkelit dalam kesalalahnya. Akantepi, masih banyak kelonggaran dalam penangan kasus tersebut. Peraturan yang dibuat masih begitu umum sehingga penjelasan kurang spesifik. Para aktor pelanggar selalu bisa berkelit dariUU ITE yang sudah ada. Perlunya ada perubahan-perubahan yang mendalam dan peraturan itu dapat mengikuti perubahan zaman dan teknologi yang ada. Lahirlah UU ITE yang terbaru, UU ini diluncurkan pada tahun 2019 mengingat semakin banyaknya pelanggaran di dunia maya melalui media sosial. Dengan adanya UU ITE yang baru Generasi melenialtidak terpengaruh dalam menggunakan media sosial, penggunya semakin besar. Generasi melenial terus berevolusi menjadi manusia yang modern dengan ditumpangi teknologi canggih. Batas-batas yang dulu dianggap tabu, pada generasi melenial ini melewati batsasan tersebut. Perbedaan yang ada di dunia semakin hilang, sekat-sekat kebudayan pun semakin memudar. Hal ini akibat Generasi melenial cenderung melupakan budaya yang ada sedangkan UU ITE tidak bisa mengikat hal tersebut. UU ITE hanya bisa menurunkan hal-hal yang menyimpang dan melanggar hukum saja. Perkembangan UU ITE ini tidak dapat membatasi ekspresi, kreatifitas dan inovatif dari generasi melenial. UU ITE ini membangun generasi yang modern dan berilmu dalam mengarungi perubahan sosial melalui media sosial yang ada. Media sosial yang digunakan sekarang lebih berguana dalam memenuhi segala aspek kehidupan.
Dalam Undang-Undang Informasi dan Transaksi Elektronik (UU ITE), pada Pasal 40 ayat (2a) memberikan kewenangan kepada pemerintah untuk mencegah dan memblokir situs yang memuat informasi-informasi tertentu. Kemudian pada Pasal 40 ayat (2b) UU ITE juga menegaskan bahwa dalam mencegah menyebarnya konten-konten negatiff atau konten yang dinilai melanggar aturan, pemerintah dapat saja memerintahkan para pihak penyelenggara informasi (dalam hal ini penyedia jaringan internet) untuk melakukan pemutusan akses terhadap layanan akses informasi, termasuk media sosial.

Kemudian, merujuk pada Pasal 4 ayat (1) Kovenan Internasional tentang Hak Sipil dan Hak Politik (ICCPR) yang telah diratifikasi dalam UU No 12 Tahun 2005, menegaskan bahwa dalam keadaan yang yang mendesak dan membahayakan kehidupan bangsa dan masyarakat banyak, pemerintah sebegai pengambil kebijakan dalam suatu Negara berwenang untuk tidak memenuhi kewajiban - kewajibannya dalam melaksanakan aturan internasional mengenai pemenuhan hak asasi manusia. Dalam hal ini artinya Negara memiliki kewenangan untuk membatasi hak asasi manusia, termasuk dalam hal membatasi hak masyarakat untuk memperoleh informasi melalui internet atau media sosial.

Namun pembatasan tersebut harus memenuhi 2 (dua) syarat yang telah diisyaratkan dalam salah satu pasal yang terdapat pada kovenan internasional yang mengatur mengenai hak-hak sipil dan politik tersebut, yaitu :

1. Situasi Negara dalam keadaan darurat yang membahayakan kehidupan bangsa. 2. Negara telah melakukan penetapan keadaan darurat secara resmi. Dalam peraturan-peraturan tersebut sebenarnya dapat menimbulkan persoalan karena 
tidak diatur mengenai prosedur atau tata cara untuk melakukan pembatasan tersebut. Prosedur ini tentunya sangat penting agar pemerintah tidak menyalah gunakan kewenangan terhadap pembatasan tersebut. Dan ukuran untuk informasi yang terdapat didalam media sosial yang dapat dikatakan sebagai informasi yang membahayakan Negara juga belum jelas. Selain itu Media Sosial juga tidak hanya digunakan untuk menyampaikan atau memperoleh informasi, namun juga digunakan untuk tujuan lain seperti ekonomi, hiburan, dan lainlain. Oleh karena itu, kewenangan pemerintah terhadapat pembatasan media sosial ini harus lebih diatur lebih jelas lagi prosedurnya, sehingga tidak menimbulkan kerugian di masyarakat. Kemudian jika melihat lebih jauh lagi sebenarnya Pasal 40 UU ITE sendiri hanya memberikan kewenangan kepada pemerintah untuk melakukan pembatasan atau pemblokiran akses hanya terhadap informasi elektronik yang dinilai "Melanggar Hukum" saja, tidak seluruh aksesnya. Ketika melalukan pembatasan itu pun pemerintah harus melibatkan masyarat dan wajib memberi pernyataan resmi di awal kepada publik bahwa layanan akses informasi di media sosial telah dibatasi. Hal ini sesuai dengan esensi dari Pasal 7 Permenkominfo No 19 Tahun 2014 mengenai pencegahan terhadap meluasnya konten-konten negative di dunia maya atau internet yang memuat partisipasi masyarakat dalam pemblokiran konten negatif di dunia maya atau internet. Bedasarkan uraian tersebut, maka kewenangan pemerintah dalam membatasi layanan akses pada media sosial diakui oleh peraturan perundang-undangan, namun pembatasan tersebut tidak memiliki prosedur hukum yang jelas. Prosedur atau tata cara ini sangat penting, karena jika tidak diatur maka akan berpotensi menimbulan kesewenang-wenangan atau abuse of power oleh pemerintah terhadapat hak-hak asasi warga negaranya.

\section{PENUTUP}

Media sosial merupakan alat untuk berkomunikasi, ekspresi, inovasi, kreatif yang dibungkus dalam flatfrom digital elektronik. Kegunaan media sosial sangatlah penting dalam menemeni kehidupan sehari-hari. Dalam penggunaannya yang banyak terpengaruh adalah generasi melenial. Generasi saat ini mereka mengatakan diri mereka adalah generasi melenial. Indikasi pengataan ini dimana sekelompok anak muda yang menggunakan teknologi sebagai alat aktifitasnya.

Untuk mengikuti perubahan yang ada pada prilaku generasi saat ini maka pemerintahan membuatkan perlindungan para pengguna dalam wujud UU ITE. Undang-undang ini tidak mengikat kebebasan generasi melenial melainkan melindungi dari para penjahat cyber.Untuk itu perlunya perlindungan yang dibawahi pemerintah pusat melalui badan hukum terikat. Generasi melenial ini merupakan generasi yang diharapkan untuk membangun Negara Indonesia dimasa yang akan datang. UU ITE tentang Efek media sosial terhadap generasi melenial, menyimpulkan bahwa media sosial mencerminkan begitu penting terhadap perkembangan generasi melenial menuju masyarakat yang modern dan memiliki jiwa yang tangguh, kreatif dan inovatif.

\section{DAFTAR PUSTAKA}

Baudrillard, J. 1994. Simulacra and simulation. Ann Arbor: University of Michigan Press 
Endang Retnowati, 2012, Keterbukaan Informasi Publik dan Good Governance (Antara Das Dein dan Das Solen), Jurnal Perspektif, Vol. 17, No. 1 Januari 2012.

Https://id.m.

Wikipedia.org/wiki/Milenial\#cite_n ote-1

Kaplan, Andreas M.; Michael Haenlein. 2010. Users of the Word, United The Challenges and opportunities of Sosial Media. Business Horizons

Kemenfo, 2019" UU ITE" https://www.kominfo.go.id/

Laughey, D. 2007. Themes in mediatheory.New York: Open University Press

Luh Gede Mega Kharisma, 2016, Kedudukan Komisi Nasional Hak Asasi Manusia Sebagai Lembaga Negara Independen Dalam Sistem Ketatanegaraan Indonesia, Jurnal Kertha Negara, Vol. 04, No. 05, Juli 2016.

Mardalis. 2004. Metode Penelitian (Suatu Pendekatan Proposal). Jakarta: Bumi

Nasrullah, R. 2015. Media sosial (perspektif komunikasi, budaya, dan sosioteknologi). Jakarta: Simbiosa Rekatama Media

Nawawi, Handari. 1993. Metode Penelitian Bidang Sosial. Yogyakarta: UGM Pers

Nunuk Febriananingsih, Keterbukaan Informasi Publik Dalam Pemerintahan Terbuka Menuju Tata Pemerintahan Yang Baik, Jurnal Rechts Vinding, Vol. 1, No.1 Januari - April 2012.

irajuddin, Didik Sukriono, Windardi, 2011, Hukum Pelayanan Publik Berbasis Partisipasi dan
Keterbukaan Informasi, Setara Press, Malang.

Sugiyono. 2012. Metode Penelitian Kuantitatif Kualitatif dan R\&D. Bandung: Alfabeta.

Wahono, RomiSatria. 2008. "Analisa UU ITE," http://romisatriawahono.net/2008/04 /24/analisa-uu-ite/. 